\title{
Endocrine disruptors and rat adrenocortical function: Studies on freshly dispersed and cultured cells
}

\author{
AGNIESZKA ZIOLKOWSKA ${ }^{1}$, ANNA S. BELLONI ${ }^{2}$, GASTONE G. NUSSDORFER ${ }^{2}$, \\ MAGDALENA NOWAK ${ }^{1}$ and LUDWIK K. MALENDOWICZ ${ }^{1}$ \\ ${ }^{1}$ Department of Histology and Embryology, Poznan University of Medical Sciences, PL-60781 Poznan, Poland; \\ ${ }^{2}$ Department of Human Anatomy and Physiology, Section of Anatomy, School of Medicine, \\ University of Padua, Via Gabelli 65, I-35121 Padua, Italy
}

Received July 5, 2006; Accepted September 1, 2006

\begin{abstract}
The effects of four endocrine disruptors: resveratrol, diphenylolpropane (bisphenol-A; BSP), benzophenone-3 (BP3) and silymarin on the secretory and proliferative activity of rat adrenocortical cells were investigated in vitro. Resveratrol and BP3 acutely increased basal corticosterone secretion from freshly dispersed adrenocortical cells, and resveratrol and BSP enhanced ACTHstimulated cells. The 24-h exposure to resveratrol and BP3 increased basal corticosterone production from cultured adrenocortical cells, while ACTH-stimulated secretion was increased only by resveratrol. BSP was ineffective, while silymarin decreased basal, but not ACTH-stimulated secretion. The proliferative activity of the cultured adrenocortical cells was unaffected by the tested disruptors. In conclusion, the in vitro direct effect of endocrine disruptors on adrenocortical steroidogenesis displays a great variability, which seems to depend not only on their chemical nature, but also on their dose and the duration of the exposure of the studied cells.
\end{abstract}

\section{Introduction}

Endocrine disruptors (ED) are both naturally occurring and synthetic chemicals, which exert adverse effects on an organism or its progeny acting through the endocrine system (1). The best recognized endocrine-disrupting properties of chemicals are those connected with their estrogenic activity (reviewed in ref. 2). Adrenal glands are very sensitive to estrogens (3 and refs. therein), but, as underlined by Harvey and Everett (4), the current in vitro testing strategies to assess

Correspondence to: Professor G.G. Nussdorfer, Department of Human Anatomy and Physiology, Section of Anatomy, University of Padua, Via Gabelli 65, I-35121 Padua, Italy

E-mail: gastone.nusdorfer@unipd.it

Key words: adrenocortical cells, steroidogenesis, resveratrol, bisphenol-A, benzophenone-3, silymarin the effects of ED have omitted these glands as far as either steroidogenesis or growth are concerned.

Hence, we investigated the direct effects of some ED, including resveratrol, diphenylolpropane (bisphenol-A, BSP), benzophenone-3 (Eusolex-4360, BP3) and silymarin, on freshly dispersed and cultured rat adrenocortical cells.

\section{Materials and methods}

Animals and reagents. Adult female Wistar rats (130-140 g body weight), bred in our animal facilities, were kept under a 14:10-h light-dark cycle at $23^{\circ} \mathrm{C}$, and maintained on a standard diet and tap water ad libitum. Rats were decapitated, and their adrenal glands were promply removed and freed of adherent fat. The study protocol was approved by the local Ethics Committee for Animal Studies. BSP and BP3 were purchased from Merck \& Co. (Whitehouse Station, NJ), and resveratrol was obtained from Nabio Biotech. Co. (Shanghai, China). Silymarin, Dulbecco's modified Eagle's medium (DMEM), fetal calf serum (FCS), bovine serum albumin (BSA), and all other chemicals and reagents were provided by Sigma-Aldrich Corp. (St Louis, MO).

Dispersed adrenocortical cells. Adrenal glands were decapsulated to separate zona glomerulosa, and enucleated to eliminate medullary chromaffin tissue. Dispersed zona fasciculata-reticularis cells were obtained by sequential collagenase-I digestion and mechanical disaggregation (5). Dispersed cells obtained from adrenals of 8 rats were pooled to obtain a single cell suspension, and 6 cell suspensions for each incubation experiment were used. Cells were counted with a CASY-cell counter (Model TT; Schaerfe System, Reutlingen, Germany), and aliquots of cell suspensions $\left(10^{4}\right.$ cells $/ \mathrm{ml}$ in Krebs-Ringer bicarbonate buffer with $0.3 \%$ glucose and $0.2 \% \mathrm{BSA})$ were incubated with $\mathrm{ED}\left(10^{-12}-10^{-6} \mathrm{M}\right)$ in the presence or absence of $10^{-8} \mathrm{M}$ ACTH. ED were dissolved in ethanol and the final concentrations of the solvents were: BSP, $0.001 \%$; resveratrol, $0.006 \%$; and $\mathrm{BP} 3$ and silymarin, $0.1 \%$. The incubation was carried out in a shaking bath at $37^{\circ} \mathrm{C}$ for $120 \mathrm{~min}$ in an atmosphere of $95 \%$ air $/ 5 \% \mathrm{CO}_{2}$. At the end of the experiment, the incubation tubes were centrifuged at $4^{\circ} \mathrm{C}$, and the supernatants were stored at $-36^{\circ} \mathrm{C}$. 
Adrenocortical cell culture. Adrenal fragments were dissociated to cell suspensions by enzymatic digestion, as previously described $(6,7)$. Dispersed cells were harvested, counted, seeded at a density of $10^{4}$ cells $/ \mathrm{cm}^{2}$ into 24 -well plates, and cultured for $96 \mathrm{~h}$ at $37^{\circ} \mathrm{C}$ in DMEM with $1.125 \mathrm{~g} / \mathrm{l}$ sodium bicarbonate, $10 \%$ FCS and a penicillin-streptomycinfungizone Sigma mixture), and the medium was changed every $24 \mathrm{~h}$ (8). At day 4 of culture, adrenocortical cells were incubated for $24 \mathrm{~h}$ with ED $\left(10^{-10}-10^{-6} \mathrm{M}\right)$ and/or ACTH, as detailed above. The culture medium was collected and stored at $-36^{\circ} \mathrm{C}$.

Corticosterone assay. The corticosterone concentration in the incubation or culture medium was measured by RIA, as described earlier (9) with sensitivity, $50 \mathrm{pg} / \mathrm{ml}$; and intra- and inter-assay CVs, $7 \%$ and $9 \%$, respectively.

Cell proliferation. The proliferation rate of cultured adrenocortical cells was measured by the EZ4U nonradioactive cell proliferation and cytotoxic assay (Biomedica, Vienna, Austria) $(8,10)$. In this assay cultured cells were incubated for 90 min with EZ4U, and the formazan production, which is linearly related to the cell number, was measured at a 490-nm wavelength in a microplate autoreader (EL-13; Bio-Tek Instruments, Winooski, VT).

Statistical analysis. Data were expressed as the mean \pm SEM of 6 independent experiments, and statistical comparison was performed by ANOVA, followed by the multiple range test of Duncan.

\section{Results}

Acute effects of ED. Within 120 min of culture, resveratrol and BP3 $\left(10^{-12}-10^{-8} \mathrm{M}\right)$, but not the other ED, stimulated basal corticosterone production from dispersed adrenocortical cells, and resveratrol and BSP $\left(10^{-12} \mathrm{M}\right)$, but not the other ED, enhanced ACTH-stimulated cells (Fig. 1).

Chronic effects of ED. The 24-h exposure to resveratrol $\left(10^{-8} \mathrm{M}\right)$ and BP3 $\left(10^{-10} \mathrm{M}\right)$ increased basal corticosterone secretion from cultured adrenocortical cells; BSP was ineffective, while silymarin $\left(10^{-10}\right.$ and $\left.10^{-8} \mathrm{M}\right)$ lowered it. Resveratrol $\left(10^{-6} \mathrm{M}\right)$, unlike the other ED, also enhanced ACTHstimulated corticosterone secretion (Fig. 2). As expected, ACTH decreased the proliferative activity of cultured adrenocortical cells (reviewed in ref. 3). None of the tested ED affected the growth of the cultured cells (Fig. 2).

\section{Discussion}

Our present study provided results in part conflicting with the previous scarce findings concerning the effects of ED on adrenal glands. To summarize: i) basal corticosterone secretion was increased by the acute and chronic exposure to both resveratrol and $\mathrm{BP} 3$; ii) the ACTH-stimulated corticosterone response was enhanced by the acute and chronic exposure to resveratrol and by the chronic exposure to BSP, and was inhibited by the chronic exposure to silymarin; and iii) ED did not alter the proliferative activity of cultured cells.
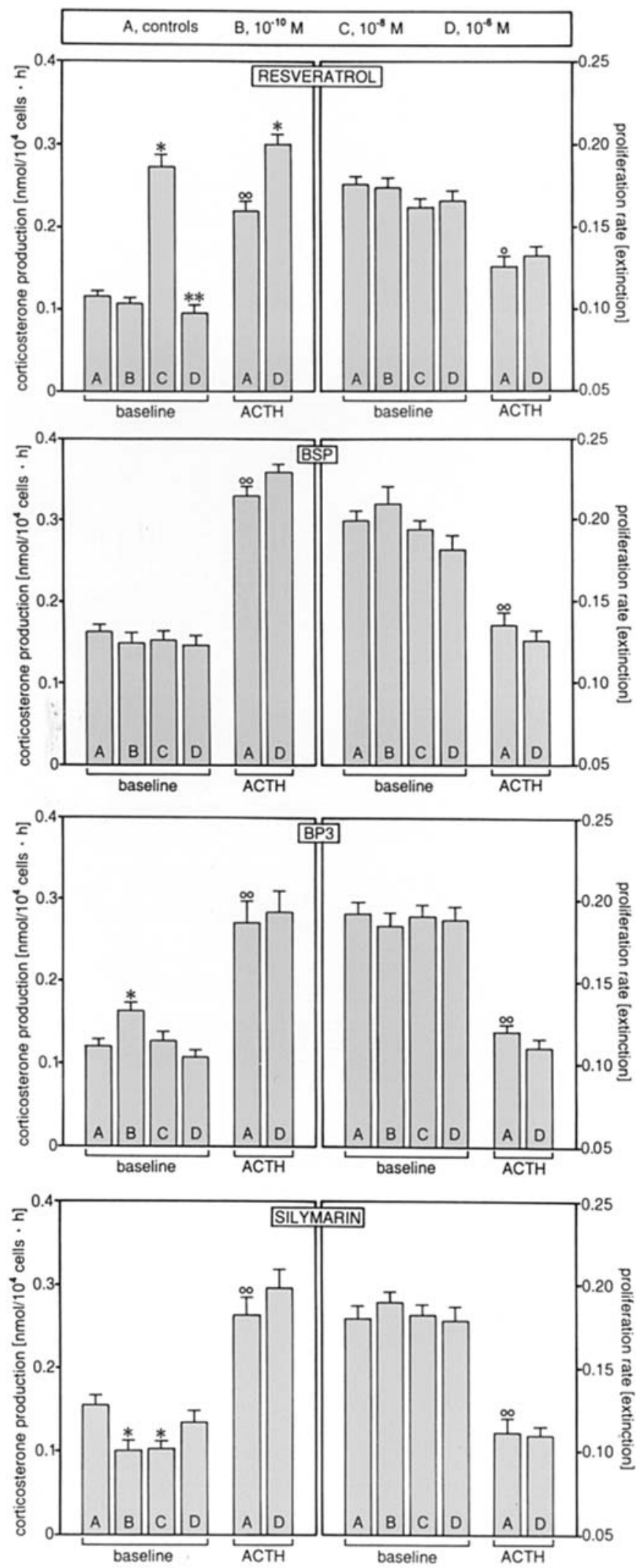

Figure 1. Effects of ED on corticosterone secretion from freshly dispersed rat adrenocortical cells. Bars are means \pm SEM of 6 separate experiments. ${ }^{*} \mathrm{P}<0.05$ and ${ }^{* *} \mathrm{P}<0.01$ from the respective controls; ${ }^{\circ} \mathrm{P}<0.01$ from baseline value.

The phytoestrogen resveratrol, which exhibits selective estrogen receptor-modulating activity $(11,12)$, has been previously reported to inhibit the cytochrome $\mathrm{P}_{450} \mathrm{c} 21$ - 
A, controls B, $10^{-12} \mathrm{M} \mathrm{C}, 10^{-10} \mathrm{M} \mathrm{D}, 10^{-8} \mathrm{M} \mathrm{E}, 10^{-6} \mathrm{M}$
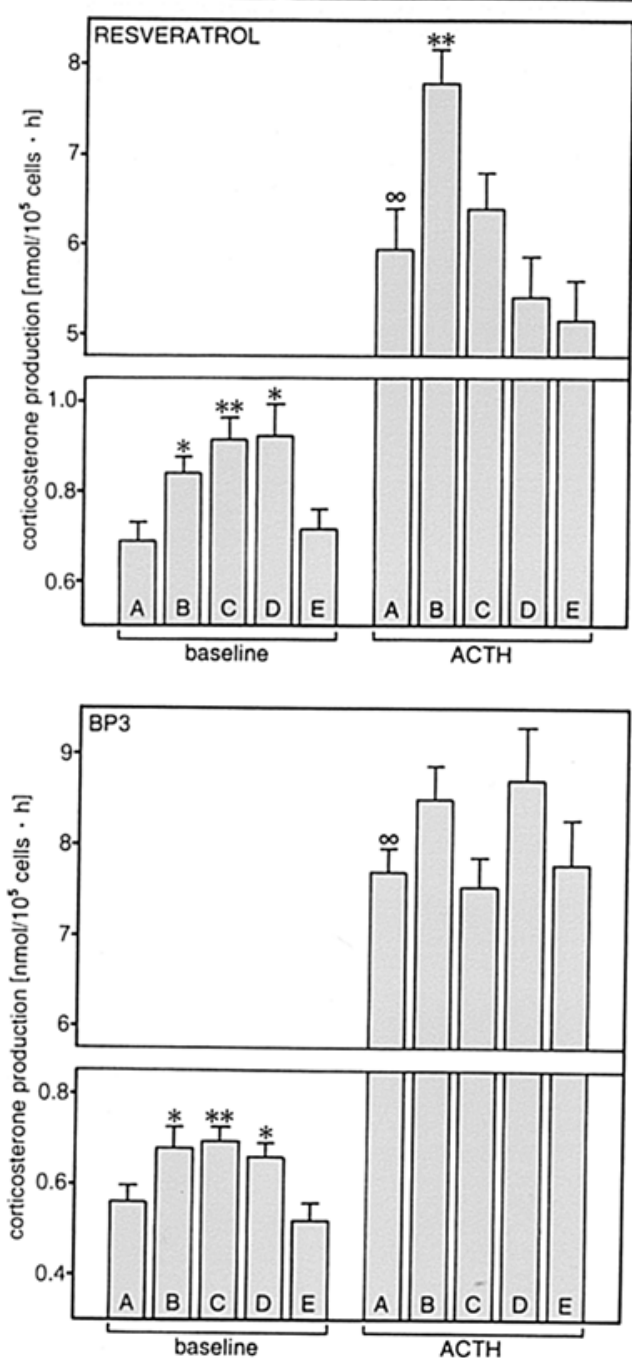

A, controls B, $10^{-12} \mathrm{M} \mathrm{C}, 10^{-10} \mathrm{M} \mathrm{D}, 10^{-6} \mathrm{M} \mathrm{E}, 10^{-6} \mathrm{M}$
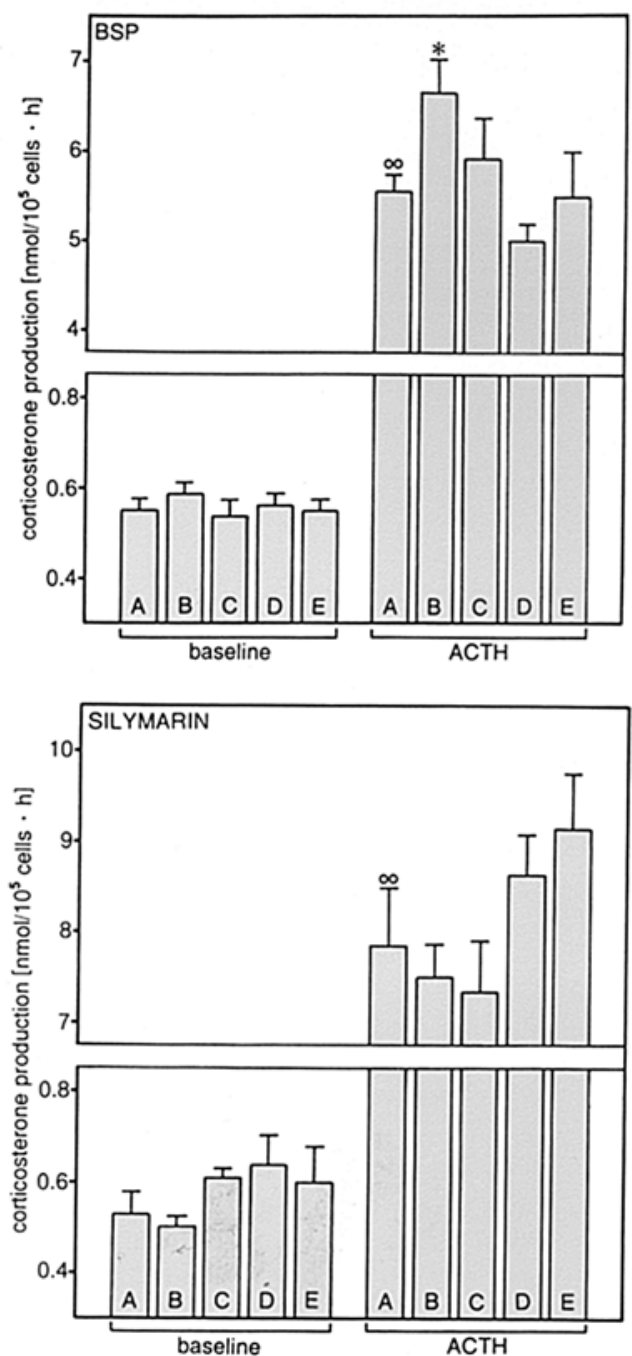

Figure 2. Effects of ED on corticosterone secretion from and the proliferative activity of cultured rat adrenocortical cells. Bars are means \pm SEM of 6 separate experiments. ${ }^{*} \mathrm{P}<0.05$ and ${ }^{* *} \mathrm{P}<0.01$ from the respective controls; ${ }^{\circ} \mathrm{P}<0.01$ from baseline value.

hydroxylase activity of and ACTH-stimulated corticosterone release from cultured rat adrenocortical cells (13). Our findings, indicating that resveratrol is the main in vitro adrenocortical secretagogue, are in complete disagreement with these observations. However, it must be noted that Supornsilchai et al (13) used adrenocortical cells obtained from rats either maintained on a normal or a resveratrolcontaining diet for 12 weeks. The cultured cells were exposed for $48 \mathrm{~h}$ to a resveratrol concentration 2-fold higher than the maximal concentration used in our experiments $\left(10^{-4}\right.$ versus $10^{-6} \mathrm{M}$ ). Although resveratrol has been reported to inhibit the growth of a breast cancer-derived cell line MCF-7 (14), in vivo experiments did not evidence any effect of this ED on the mitotic activity of regenerating rat adrenal glands (15), and our present findings agree with these last observations.

BP3 is a UV-absorber, which displays structural relationships with steroid hormones (16). Previous in vivo studies evidenced no effect of BP3 on corticosterone blood levels in rats with regenerating adrenals (15). This observation is in contrast with our present findings indicating a net in vitro adrenocortical secretagogue action of this ED. BP3 was found to raise the proliferative activity of regenerating rat adrenals (15), an MCF-7 cell line (17) and cultured bone marrowderived mesenchymal stem cells (18), but our investigation showed no effect of this ED on in vitro cultured adrenocortical cells.

BSP and alkylphenols are ED possessing estrogenic activity $(19,20)$. In vivo studies found no effect of BSP on rat adrenal cortex secretion and growth $(15,21)$. Our study is in partial disagreement with these findings, inasmuch as it demonstrated a minor acute stimulating action of low concentrations of BSP on corticosterone secretion in the presence of ACTH.

The plant flavonoid silymarin (22) has been shown to exert estrogen-like effects on the metaphysis of the femur of ovariectomized rats (23), but in vivo experiments found no effect of this ED on rat adrenals (15). Our present findings, showing that the prolonged exposure to silymarin decreased basal corticosterone production from cultured rat adrenocortical cells, may suggest a toxic effect of silymarin independent of its estrogen receptor-modulating activity. 
In conclusion, our study demonstrates variable direct effects of ED on adrenocortical steroidogenesis. This variability appears to depend not only on the chemical nature of ED, but also on their concentrations and the duration of exposure; key factors which must be taken into account in studies on the effect of endocrine receptors on the adrenal cortex.

\section{Acknowledgements}

This study was supported by the European Community grant EURISKED EVK1-CT2002-00128. The author wishes to thank Miss A. Coi for her secretarial support and her invaluable help in the provision of bibliographic items.

\section{References}

1. Pombo $\mathrm{M}$ and Castro-Feijóo L: Endocrine disruptors. J Pediat Endocrinol Metab 18: 1145-1155, 2005.

2. Tabb MM and Blumberg B: New modes of action for endocrine-disrupting chemicals. Mol Endocrinol 20: 475-482, 2006.

3. Nussdorfer GG: Cytophysiology of the adrenal cortex. Int Rev Cytol 98: 1-405, 1986.

4. Harvey PW and Everett DJ: The adrenal cortex and steroidogenesis as cellular and molecular targets for toxicity: critical omissions from regulatory endocrine disrupter screening strategies for human health? J Appl Toxicol 23: 81-87, 2003.

5. Belloni AS, Rossi GP, Andreis PG, Neri G, Albertin G, Pessina AC and Nussdorfer GG: Endothelin adrenocortical secretagogue effect is mediated by the $\mathrm{B}$ receptor in rats. Hypertension 27 : 1153-1159, 1996.

6. Ziolkowska A, Carraro G, Rebuffat P, Spinazzi R, Nussdorfer GG, Rucinski M and Malendowicz LK: Beacon[47-73] inhibits glucocorticoid secretion and growth of cultured rat and human adrenocortical cells. Int J Mol Med 14: 457-461, 2004.

7. Rucinski M, Albertin G, Spinazzi R, Ziolkowska A, Nussdorfer GG and Malendowicz LK: Cerebellin in the rat adrenal gland: Gene expression and effects of CER and [des-Ser $\left.{ }^{1}\right]$ CER on the secretion and growth of cultured adrenocortical cells. Int J Mol Med 15: 411-415, 2005.

8. Spinazzi R, Ziolkowska A, Neri G, Nowak M, Rebuffat P, Nussdorfer GG, Andreis PG and Malendowicz LK: Orexins modulate the growth of cultured rat adrenocortical cells, acting through type 1 and type 2 receptors coupled to the MAPK p42/p44- and p38-dependent cascades. Int J Mol Med 15: 847-852, 2005.

9. Hochol A, Albertin G, Nussdorfer GG, Spinazzi R, Ziolkowska A, Rucinski M and Malendowicz LK: Effects of neuropeptides B and $\mathrm{W}$ on the secretion and growth of rat adrenocortical cells. Int J Mol Med 14: 843-848, 2004.
10. Malendowicz LK, Rebuffat P, Tortorella C, Nussdorfer GG, Ziolkowska A and Hochol A: Effects of met-enkephalin on cell proliferation in different models of adrenocortical-cell growth. Int J Mol Med 15: 841-845, 2005.

11. Cos P, De Bruyne T, Apers D, Van den Berghe D, Pieters L and Vlietinck AJ: Phytoestrogens: recent developments. Planta Med 69: 589-599, 2003.

12. Granados-Soto V: Pleiotropic effects of resveratrol. Drug News Perspect 16: 299-307, 2003.

13. Supornsilchai V, Svechnikov K, Seidlova-Wuttke D, Wuttke W and Soder O: Phytoestrogen resveratrol suppresses steroidogenesis by rat adrenocortical cells by inhibiting cytochrome $\mathrm{P}_{450}$ c21-hydroxylase. Horm Res 64: 280-286, 2005.

14. Lanzilli G, Fuggetta MP, Tricarico M, Cottarelli A, Serafino A, Falchetti R, Ravagnan G, Turriziani M, Adamo R, Franzese O and Bonmassar E: Resveratrol down-regulates the growth and telomerase activity of breast cancer cells in vitro. Int J Oncol 28: 641-648, 2006.

15. Malendowicz LK, Trejter M, Rebuffat P, Ziolkowska A, Nussdorfer GG and Majchrzak M: Effects of some endocrine disruptors on the secretory and proliferative activity of the regenerating rat adrenal cortex. Int J Mol Med 18: 197-200, 2006.

16. Gustavsson-Gonzales H, Farbrot A and Larko O: Percutaneous absorption of benzophenone-3, a common component of topical sunscreens. Clin Exp Dermatol 27: 691-694, 2002.

17. Schlumpf M, Cotton B, Conscience M, Haller V, Steinmann B and Liechtensteiger W: In vitro and in vivo estrogenicity of $\mathrm{UV}$ screens. Environ Health Perspect 109: 239-244, 2001.

18. Pan W, Quarles LD, Song LH, Yu YH, Jiao C, Tang HB, Jiang CH, Deng HW, Li YJ, Zhou HH and Xiao ZS: Genistein stimulates the osteoblastic differentiation via NO/cGMP in bone marrow culture. J Cell Biochem 94: 307-316, 2005.

19. Ashby J: Increasing the sensitivity of the rodent uterotrophic assay to estrogens, with particular reference to bisphenol A. Environ Health Perspect 109: 1091-1094, 2001.

20. Seidlova-Wuttke D, Jarry H, Christoffel J, Rimoldi G and Wuttke W: Effects of bisphenol-A (BPA), dibutylphatalate (DBP), benzophenone-2 (BP2), procymidone (Proc), and linurone (Lin) on fat tissue, a variety of hormones and metabolic parameters: a 3 months comparison with effects of estradiol (E2) in ovariectomized (ovx) rats. Toxicology 213: 13-24, 2005.

21. Aloisi AM, Della Seta D, Rendo C, Ceccarelli I, Scaramuzzino A and Farabollini F: Exposure to the estrogenic pollutant bisphenol-A affects pain behavior induced by subcutaneous formalin injection in male and female rats. Brain Res 937: 1-7, 2002.

22. Katiyar SK: Silymarin and skin cancer prevention: antiinflammatory, antioxidant and immunomodulatory effects. Int $\mathrm{J}$ Oncol 26: 169-176, 2005.

23. Seidlova-Wuttke D, Becker T, Christoffel J, Jarry H and Wuttke W: Silymarin is a selective estrogen receptor beta (ERbeta) agonist and has estrogenic effects in the metaphysis of the femur, but no or antiestrogenic effects in the uterus of ovariectomized (ovx) rats. J Steroid Biochem Mol Biol 86: 179-188, 2003. 